\title{
The lipoprotein lipase gene in combined hyperlipidemia: evidence of a protective allele depletion Shu-Fen Wung ${ }^{\dagger 1}$, Medha V Kulkarni ${ }^{\dagger 2}$, Clive R Pullinger ${ }^{\dagger 2,3}$, Mary J Malloy ${ }^{\dagger 3}$, John P Kane ${ }^{\dagger 3}$ and Bradley E Aouizerat*†2,4
}

\author{
Address: ${ }^{1}$ College of Nursing, University of Arizona, Tucson, AZ, USA, ${ }^{2}$ Department of Physiological Nursing, School of Nursing, University of \\ California San Francisco, San Francisco, CA, USA, ${ }^{3}$ Cardiovascular Research Institute, University of California San Francisco, San Francisco, CA, \\ USA and ${ }^{4}$ Center for Human Genetics, University of California San Francisco, San Francisco, CA, USA \\ Email: Shu-Fen Wung - shufen@nursing.arizona.edu; Medha V Kulkarni - medha.kulkarni@ucsf.edu; \\ Clive R Pullinger - clive.pullinger@ucsf.edu; Mary J Malloy - mary.malloy@ucsf.edu; John P Kane - john.kane@ucsf.edu; \\ Bradley E Aouizerat* - bradley.aouizerat@ucsf.edu \\ * Corresponding author †Equal contributors
}

Published: 05 July 2006

Lipids in Health and Disease 2006, 5:19 doi:10.1186/1476-511X-5-19

This article is available from: http://www.lipidworld.com/content/5/I//9

(C) 2006 Wung et al; licensee BioMed Central Ltd.

This is an Open Access article distributed under the terms of the Creative Commons Attribution License (http://creativecommons.org/licenses/by/2.0), which permits unrestricted use, distribution, and reproduction in any medium, provided the original work is properly cited.
Received: 10 May 2006

Accepted: 05 July 2006

\begin{abstract}
Background: Lipoprotein Lipase (LPL), a key enzyme in lipid metabolism, catalyzes the hydrolysis of triglycerides (TG) from TG-rich lipoproteins, and serves a bridging function that enhances the cellular uptake of lipoproteins. Abnormalities in LPL function are associated with pathophysiological conditions, including familial combined hyperlipidemia $(\mathrm{FCH})$. Whereas two LPL susceptibility alleles were found to co-segregate in a few FCH kindred, a role for common, protective alleles remains unexplored. The LPL Ser447Stop (S447X) allele is associated with anti-atherogenic lipid profiles and a modest reduction in risk for coronary disease. We hypothesize that significant depletion of the $447 \mathrm{X}$ allele exists in combined hyperlipidemia cases versus controls. A casecontrol design was employed. The polymorphism was assessed by restriction assay in 212 cases and $16 \mathrm{I}$ controls. Genotypic, allelic, and phenotypic associations were examined.
\end{abstract}

Results: We found evidence of significant allelic $\left(447 \mathrm{X}_{\text {control }}: 0.130\right.$ vs. $447 \mathrm{X}_{\text {case }}: 0.03 \mathrm{I}, \chi^{2}=29.085$; Idf; $p<0.00 I$ ) and genotypic association (SS: 0.745 vs. 0.939 , and $S X+X X: 0.255$ vs. $0.06 \mathrm{I}$ ) in controls and cases, respectively $\left(\chi^{2}=26.09\right.$; Idf; $\left.p<0.00 \mathrm{I}\right)$. In cases, depletion of the 447X allele is associated with a significant elevation in very-low-density lipoprotein cholesterol (VLDL-C, $\mathrm{p}=$ 0.045). Consonant with previous studies of this polymorphism, regression models predict that carriers of the $447 \mathrm{X}$ allele displayed significantly lower TG, low-density lipoprotein cholesterol (LDL-C) and TG/high-density lipoprotein cholesterol (HDL-C) ratio.

Conclusion: These findings suggest a role for the S447X polymorphism in combined hyperlipidemia and demonstrate the importance of evaluating both susceptibility and protective genetic risk factors.

\section{Background}

Abnormalities of lipoprotein metabolism play an important role in the development of atherosclerosis $[1,2]$, and was one of the earliest established biochemical links to cardiovascular disease [3]. It is well established that elevated plasma triglycerides (TG) are an independent risk 
factor for coronary heart disease (CHD), and not simply a marker of an inverse relationship with high density lipoprotein-cholesterol (HDL-C), also an independent risk factor for disease [4]. The relative risk of CHD associated with a 1-mmol/L increase in TG was 1.32 (95\% CI: 1.26$1.39)$ in men and 1.76 (95\% CI: 1.5-2.07) in women [4]. Thus, identifying factors that determine plasma TG is desirable.

The contribution of lipoprotein lipase (LPL) in the development of dyslipidemia and atherosclerosis is increasingly recognized [5-7]. Numerous studies have shown that LPL is a key enzyme that plays a central role in lipoprotein metabolism and transport [8] and substantial evidence suggests that LPL has an important influence on TG levels [9]. In addition, LPL possesses a non-enzymatic bridging function, assisting in cellular lipoprotein uptake [10]. The finding of triglyceride-rich lipoproteins (TRL) in human atheromata $[11,12]$ has provided substantial pathophysiologic evidence for a direct role of LPL in atherogenesis. Importantly, hereditary forms of dyslipidemia have been in part attributed to ablative mutations in LPL [13].

Though over 200 coding mutations within the LPL gene (MIM 609708) have been described, the role for common functional polymorphism of LPL, particularly in familial combined hyperlipidemia (FCH [MIM 144250]), remains poorly explored $[14,15]$. The most common amino acid change in LPL is Ser447X (rs328; formally p.Ser474X, c. $1421 \mathrm{C}>\mathrm{G}$; but throughout the present report we have kept to the traditional nomenclature for this polymorphism), resulting in an LPL protein truncated by two amino acids [16]. It appears likely that the functional properties of the $447 \mathrm{X}$ truncated LPL protein is an enhanced bridging function, leading to increased clearance of TRL from the circulation [5]. Interestingly, recent cohort studies suggest that LPL 447X carriers appear to have a more favorable lipid profile and this allele appears to be a negative risk factor for coronary artery disease (CAD) [17-19]. An interesting recent report of neonatal somatic gene transfer with an adenoviral vector containing the S447X variant of LPL described rescue of 95\% of LPL-deficient mice from lethality [20]. This study is further evidence of the gain of function of the S447X variant, as pointed out by Rader [21], because considerably fewer animals were rescued when the wild-type LPL vector had been used previously [22].

FCH is the most prevalent genetic lipid disorder observed in patients with CAD and their relatives, with a frequency of $1-2 \%$ in all populations examined and a prevalence of $10 \%-20 \%$ in patients with premature CAD [23-27]. Hypertriglyceridemia is a major component of the phenotype of FCH, the most common of the dyslipidemias [25-
27]. The common metabolic defect in FCH appears to be hepatic overproduction of apolipoprotein B-containing TRL $[28,29]$ and a preponderance of small dense low-density lipoprotein (LDL) particles [30,31]. Previously, we and others have proposed a genetic model for FCH that postulates the existence of both a common dominant major gene(s) that is further influenced by a number of modifier genes [23]. The identification of modifier genes could assist in finding the as yet undiscovered primary genetic determinant(s) by reducing the genetic heterogeneity of FCH [23].

Several reports have noted the presence of multiple lipoprotein phenotypes in obligate heterozygotes for LPL mutations that are reminiscent of FCH (i.e., hypertriglyceridemia, hypercholesterolemia, or both) [32]. As much as one-third of FCH patients have levels of post-heparin LPL activity and mass below the $10^{\text {th }}$ percentile for the general population [32,33]. Given the multifactorial nature of $\mathrm{FCH}$, with other genetic or environmental factors (e.g., obesity) causing an increase in the hepatic production of lipoproteins, the catabolic capacity of LPL in individuals who are genetically predisposed to a low basal level of LPL activity may be overwhelmed, exacerbating the primary dyslipidemia and thus accelerating atherosclerosis [23]. Importantly, studies that have examined the role of genetic variation of the LPL gene in FCH have focused primarily on rare variations, mutations or intragenic markers [23,34-38].

The possibility that a disorder could be explained, at least in part, by either enrichment of pro-atherogenic genetic variations or depletion of anti-atherogenic ones led to our interest in examining the later in combined hyperlipidemia. The occurrence of impaired LPL activity in individuals with FCH suggested that examination of the antiatherogenic LPL 447X allele could introduce a novel paradigm in the study of this disease. The aim of this study was to investigate the role of the LPL S447X polymorphism in a sample of subjects with combined hyperlipidemia and compare them with healthy controls. We provide evidence of a genetic association with LPL S447X with FCH and with lipoprotein composition in affected individuals.

\section{Results}

\section{Characteristics of the study groups}

Based Baseline on the hypothesis that a functional variation at the LPL gene locus would differ in frequency between dyslipidemic individuals and healthy controls, we screened patients and control subjects for the S447X polymorphism. The clinical characteristics of the two groups are described in Table 1. Individuals with combined hyperlipidemia displayed significantly elevated VLDL-TG $(\mathrm{t}=-15.310,286.34 \mathrm{df}, \mathrm{p}<0.001)$, LDL-TG $(\mathrm{Z}$ 
Table I: Clinical characteristics and lipid analyses of the study population.

\begin{tabular}{|c|c|c|c|}
\hline Trait & Controls $(n=|6|)$ & Cases $(n=212)$ & $\mathrm{P}$-value \\
\hline Age & $46.8 \pm 19.57(161)$ & $53.2 \pm 12.08(211)$ & $<0.001$ \\
\hline Gender(\%female) & $49.1(161)$ & $4 I .5(2 \mid 2)$ & $<0.09$ \\
\hline $\mathrm{TC}$ & $183.9 \pm 36.66(161)$ & $293.9 \pm 72.83(212)$ & $*$ \\
\hline TG & $100.0 \pm 37.81(161)$ & $376.7 \pm 347.98(212)$ & $*$ \\
\hline VLDL-C & II.I \pm 7.77 (I33) & $69.0 \pm 57.90(212)$ & $*$ \\
\hline VLDL-TG & $47.7 \pm 30.08(133)$ & $275.8 \pm 256.25(2 \mid 2)$ & $<0.001$ \\
\hline LDL-C & $\mid 22.1 \pm 31.08(133)$ & $180.5 \pm 55.96(211)$ & $*$ \\
\hline LDL-TG & $29.9 \pm 12.15(133)$ & $75.2 \pm 177.92(211)$ & $<0.001$ \\
\hline HDL-C & $52.9 \pm 14.18(158)$ & $40.6 \pm 12.48(212)$ & $<0.001$ \\
\hline HDL-TG & $15.5 \pm 4.88(158)$ & $21.7 \pm 9.68(212)$ & $<0.001$ \\
\hline TG/HDL-C & $1.97 \pm 1.42(158)$ & $11.46 \pm 17.59(212)$ & 0.211 \\
\hline BMI & $25.3 \pm 4.08$ & $27.7 \pm 4.54(154)$ & $<0.001$ \\
\hline
\end{tabular}

With the exception of gender, means and standard deviations are reported. * Use of these variables as a case selection criterion precludes report of a statistic.

TC, total cholesterol; TG, triglyceride; VLDL-C, very low density lipoprotein - cholesterol; LDL-C, low density lipoprotein-cholesterol; HDL, high density lipoprotein; BMI, body mass index.

$=-13.656, \mathrm{p}<0.001)$ and HDL-TG $(\mathrm{t}=-9.524,383.36 \mathrm{df}$, $\mathrm{p}<0.001)$ and decreased HDL-C $(\mathrm{t}=10.010,425.09 \mathrm{df}, \mathrm{p}$ $<0.001)$ compared to controls.

BMI was significantly increased in cases compared to controls $(27.7 \pm 4.54$ vs. $25.3 \pm 4.08 ; \mathrm{t}=-4.170, \mathrm{p}<0.001$ [95\% CI: $-3.53,-1.26])$.

\section{Frequencies of the SNPs}

Allelic and genotypic frequencies for S447X in cases and controls are listed in Table 2. The S447X genotype distribution did not deviate from Hardy-Weinberg expectations $\left(\chi^{2}=1.585 ; 2 \mathrm{df} ; \mathrm{p}=0.453\right)$. It is noteworthy that the allelic and genotypic frequencies of the polymorphism in the control group were similar to previous reports $[39,40]$.

Compared to healthy controls, the $447 \mathrm{X}$ allele frequency was significantly lower in cases $\left(\chi^{2}=29.085\right.$; $1 \mathrm{df} ; \mathrm{p}<$ 0.001 ; Odds Ratio $=0.192$ with 95\%CI: $0.096-0.378$ ) (Table 2). Given the limited number of observations with respect to homozygous $447 \mathrm{X}$ subjects $(\mathrm{n}=1)$, the XX and SX groups were collapsed for analysis. The genotypic distribution was significantly influenced by depletion of the $\mathrm{X}$ allele in controls versus cases $\left(\chi^{2}=26.087 ; 1 \mathrm{df} ; \mathrm{p}<\right.$
0.001; Odds Ratio $=0.191$ with 95\%CI: $0.098-0.371$ ) (Table 2A). Though no significant gender differences were observed with respect to the S447X allelic or genotypic frequencies (Table $2 \mathrm{~B}$ ), male cases versus controls displayed a slightly greater depletion of the $447 \mathrm{X}$ allele $\left(\chi^{2}=19.738\right.$; $1 d f ; \mathrm{p}<0.001$; Odds Ratio $=0.145$ with 95\%CI: $0.059-$ $0.355)$ than did female cases versus controls $\left(\chi^{2}=6.388\right.$; $1 \mathrm{df} ; \mathrm{p}=0.011$; Odds Ratio $=0.267$ with 95\%CI: 0.099 $0.716)$. In the subset of subjects for whom BMI was recorded along with baseline lipid assessments $(n=247)$, no evidence of genetic association was observed in either cases $(n=154, S S: S X+X X, p=0.216)$ or controls $(n=93$, $\mathrm{SS}: \mathrm{SX}+\mathrm{XX}, \mathrm{p}=0.615)$.

\section{Genetic association of lipid parameters with S447X}

To examine the effects of the polymorphism on lipoprotein metabolism, fasting lipoprotein concentrations provided a metabolic 'snap shot' for comparisons between carriers of the $447 \mathrm{X}$ allele and the $447 \mathrm{~S}$ homozygotes. No significant changes in mean measures of plasma lipoprotein compartments were observed in the control group (Table 3 ). With the case group the $\mathrm{S} 447$ homozygotes displayed elevated VLDL-C (SS: SX+XX, Z = -2.003, $\mathrm{p}=$ 0.045 ) (Table 4). Suggestive evidence of an association

Table 2A: Allelic and genotypic frequencies.

\begin{tabular}{lccc}
\hline & Controls $(n=161)$ & Cases $(n=212)$ & P-value \\
\hline $447 X$ & 0.130 & 0.031 & $<0.001$ \\
447 SS & 0.745 & 0.939 & 0.061 \\
447 SX & 0.248 & 0.000 & $<0.001$ \\
$447 X X$ & 0.006 & 0.0 .061 & \\
$447(S X+X X)$ & 0.255 & & \\
\hline
\end{tabular}


Table 2B: Allelic and genotypic frequencies, by gender.

\begin{tabular}{lccccc}
\hline & \multicolumn{2}{c}{ Controls } & P-value & Cases & P-value \\
& Female $(n=79)$ & Male $(n=82)$ & & Female $(n=88)$ & Male $(n=124)$ \\
\hline $447 X$ & 0.1139 & 0.1463 & 0.485 & 0.0034 & 0.0028 \\
447 SS & 0.784 & 0.707 & 0.343 & 0.932 & 0.944 \\
$447(S X+X X)$ & 0.215 & 0.293 & & 0.068 & 0.056 \\
\hline
\end{tabular}

447X, the minor allele for the lipoprotein lipase gene missense variation Serine447Stop (Ser447Ter, S447X); 447 SS, individuals homozygous for the Ser447 allele; $447(S X+X X)$, individuals that carry either one or two $447 X$ alleles.

with elevated VLDL-triglyceride (SS:SX+XX, Z = -1.883, p $=0.06$ ) and elevated HDL-TG (SS:SX+XX, Z = -1.778, $\mathrm{p}=$ 0.075 ) in carriers of the $447 \mathrm{X}$ allele was also observed (Table 4).

\section{Linear regression analysis of the effects of S447X on lipid measures}

Regression models for lipid measurements included a data-driven selection among the polymorphism category SS versus SX+XX. Potential predictors included age, gender, and clinical category (case or control). Models in which a polymorphism effect did not achieve $\mathrm{p}<0.10$ are not reported. Among the lipid measures, a logarithmic transform was found to be generally appropriate for use in the models. No significant models were indicated for TC, VLDL-C, or VLDL-, LDL-, and HDL-triglyceride. For transformed lipid measures, estimated adjusted means on the original scale are presented (Table 5).

For total triglycerides $(\mathrm{n}=372)$, the best model selected SX+XX vs. SS $(p=0.001)$. Selected effects include gender $(\mathrm{p}=0.001)$, clinical category $(\mathrm{p}<0.001)$ and genotype $(\mathrm{p}$ $=0.062$ ). The adjusted R-square for the model was 0.697 (Table 5). The group of S447 homozygotes displayed modestly elevated plasma triglycerides compared with carriers of the $447 \mathrm{X}$ allele $(+19.7 \mathrm{mg} / \mathrm{dL})$. For LDL-C $(\mathrm{n}=$ 345 ), the best model selected was also SX+XX vs. SS ( $\mathrm{p}=$ $0.007)$. Selected effects included clinical category ( $\mathrm{p}<$ $0.001)$ and genotype $(\mathrm{p}=0.087)$. The adjusted R-square for the model was 0.309 (Table 5). The group of S447 homozygotes displayed modestly elevated LDL-C as compared with carriers of the $447 \mathrm{X}$ allele $(+11.1 \mathrm{mg} / \mathrm{dL})$. For the ratio of total triglycerides to HDL-C $(n=370)$, the best model selected was again SX+XX vs. SS $(\mathrm{p}=0.031)$. Selected effects include gender $(\mathrm{p}=0.001)$, clinical category $(\mathrm{p}<0.001)$ and genotype $(\mathrm{p}=0.044)$; the adjusted R-square for the model was 0.651 (Table 5). The group of S447 homozygotes displayed modestly elevated ratio as compared with carriers of the $447 \mathrm{X}$ allele $(+0.639)$.

Though BMI measurement was available on all subjects, a measure of BMI at the same time point as the baseline

Table 3: Plasma lipid concentrations in the control sample, grouped by LPL genotype.

\begin{tabular}{|c|c|c|c|c|}
\hline & & $S S(n=120)$ & $S X+X X(n=4 I)$ & $\mathrm{P}$-value \\
\hline Age & & $45.4 \pm 18.69(120)$ & $50.8 \pm 21.67(4 I)$ & 0.131 \\
\hline BMI & & $25.5 \pm 4.38(68)$ & $25.0 \pm 3.19(25)$ & 0.615 \\
\hline \multirow[t]{4}{*}{ TG* } & Total & $92.1 \pm 36.66(120)$ & $87.9 \pm 4 I .30(4 I)$ & 0.544 \\
\hline & VLDL & $47.8 \pm 30.01$ & $47.3 \pm 30.70$ & 0.934 \\
\hline & $\mathrm{LDL}$ & $31.0 \pm 12.30(98)$ & $27.0 \pm 11.37(35)$ & 0.099 \\
\hline & HDL & $15.7 \pm 4.83(117)$ & $14.8 \pm 5.00(4 \mathrm{I})$ & 0.303 \\
\hline \multirow[t]{5}{*}{$C^{*}$} & Total & $184.8 \pm 35.19(120)$ & $|8| .3 \pm 4|.0|(4 \mid)$ & 0.654 \\
\hline & VLDL & $11.3 \pm 8.17(98)$ & $10.6 \pm 6.59(35)$ & 0.796 \\
\hline & LDL & $123.7 \pm 27.00$ & $117.5 \pm 40.53$ & 0.406 \\
\hline & HDL & $52.6 \pm 15.33(117)$ & $53.9 \pm 10.34(4 I)$ & 0.553 \\
\hline & DL-C & $2.05 \pm 1.51(117)$ & $\mathrm{I} .75 \pm \mathrm{I} .08(4 \mathrm{I})$ & 0.211 \\
\hline
\end{tabular}

*Lipid measurements expressed in $\mathrm{mg} / \mathrm{dL}$. Total cholesterol assessed by Wilcoxon two sample test.

TC, total cholesterol; TG, triglyceride; VLDL-C, very low density lipoprotein - cholesterol; LDL-C, low density lipoprotein-cholesterol; HDL, high density lipoprotein; BMI, body mass index; SS, individuals homozygous for the Ser447 allele; SX+XX, individuals that carry either one or two 447X alleles. 
Table 4: Plasma lipid concentrations in the combined hyperlipidemia subjects, grouped by LPL genotype.

\begin{tabular}{|c|c|c|c|c|}
\hline & & SS $(n=199)$ & $S X+X X(n=13)$ & $\mathrm{P}$-value \\
\hline Age & & $53.3 \pm 12.28(198)$ & $51.7 \pm 8.70(13)$ & 0.647 \\
\hline BMI & & $27.6 \pm 4.60(145)$ & $29.6 \pm 3.21(9)$ & 0.216 \\
\hline \multirow[t]{4}{*}{ TG* } & Total & $383.8 \pm 357.69(199)$ & $267.2 \pm 65.24(13)$ & 0.099 \\
\hline & VLDL & $281.7 \pm 262.98$ & $184.6 \pm 62.40(13)$ & 0.060 \\
\hline & LDL & $76.3 \pm 183.55$ (199) & $59.4 \pm 24.22(13)$ & 0.809 \\
\hline & HDL & $21.7 \pm 8.72(199)$ & $21.9 \pm 19.84(13)$ & 0.075 \\
\hline \multirow[t]{5}{*}{$C^{*}$} & Total & $295.5 \pm 73.96(199)$ & $269.2 \pm 48.10(13)$ & 0.264 \\
\hline & VLDL & $70.4 \pm 59.29(199)$ & $48.4 \pm 21.43(13)$ & 0.045 \\
\hline & LDL & $180.8 \pm 56.74(199)$ & $175.3 \pm 43.55(13)$ & 0.926 \\
\hline & $\mathrm{HDL}$ & $40.4 \pm 11.87(199)$ & $43.7 \pm 20.09(13)$ & 0.661 \\
\hline & IDLC & $11.70 \pm 18.07(199)$ & $7.82 \pm 5.849(13)$ & 0.153 \\
\hline
\end{tabular}

* Lipid measurements expressed in $\mathrm{mg} / \mathrm{dL}$. All test statistics are non-parametric (Wilcoxon two sample test).

TC, total cholesterol; TG, triglyceride; VLDL-C, very low density lipoprotein - cholesterol; LDL-C, low density lipoprotein-cholesterol; HDL, high density lipoprotein; BMI, body mass index; SS, individuals homozygous for the Ser447 allele; SX+XX, individuals that carry either one or two 447X alleles.

lipoprotein measurement was not available for all subjects. Regression models including BMI resulted in unacceptably small counts in cells, and thus analysis of the subset including BMI was not reported.

\section{Discussion}

The common S447X truncation polymorphism of LPL is associated with a cardio-protective lipid profile and a modest reduction in risk for CAD [17]. Data from this study support the hypothesis that there is significant depletion in allelic and genotypic frequencies for this protective polymorphism in individuals with combined hyperlipidemia compared to healthy controls. Specifically, we found that $447 \mathrm{X}$ exists in $13 \%$ of healthy controls but only in $3 \%$ of cases $(\mathrm{p}<0.001)$. The frequency of $447 \mathrm{X}$ in the control group is similar to that in the Framingham Offspring Study that examined 1114 men and 1144 women and found the frequency of the S447X variant was 16 and $17.5 \%$ in men and women, respectively [19]. As in a previous report [19], data from this study showed no significant gender differences with respect to the LPL allelic or genotypic frequencies, though male cases versus controls displayed a slightly greater depletion of the $447 \mathrm{X}$ allele than did female cases versus controls.

Several population studies have reported cardio-protective alterations in lipoprotein profiles in subjects who carry the 447X allele (e.g., lower TRL, lower VLDL-C, higher apo AI levels, higher HDL-C, protection against CHD) $[5,7,41-44]$. The linear regression analysis in this study showed that carriers of the $447 \mathrm{X}$ allele displayed modestly elevated plasma triglycerides $(+19.7 \mathrm{mg} / \mathrm{dL})$, LDL-cholesterol $(+11.1 \mathrm{mg} / \mathrm{dL})$, and ratio of TG over HDL-C (+0.639) as compared with carriers of the 447S allele. These results are congruent with population studies of cardiovascular disease that have reported similar effects on TG $[4,45]$, increased HDL-cholesterol, and 0.8-fold reduced risk of ischemic heart disease in $447 \mathrm{X}$ carriers. Although associations with favorable changes in both VLDL-C [42] and HDL-C have been reported, no association between LDL-C and this polymorphism has been demonstrated previously. We believe that it is likely that the case selection criterion we employed (elevated LDL-C) could potentially account for the association between the 447X allele and lower LDL-C. Although another polymor-

Table 5: Estimated adjusted means for plasma concentrations of plasma lipids, grouped according to LPL genotype.

\begin{tabular}{lccccc}
\hline Trait & $\mathrm{n}$ & $\mathrm{SS} *$ & $\mathrm{SX}+\mathrm{X} \mathrm{X}^{*}$ & $\mathrm{R}^{2}$ & $\mathrm{P}$-valuet \\
\hline TG & 373 & 165.8 & 146.1 & 0.697 & 0.001 \\
LDL-C & 345 & 144.5 & 133.4 & 0.309 & 0.007 \\
TG/HDL-C & 370 & 3.801 & 3.162 & 0.651 & 0.031 \\
\hline
\end{tabular}

* Lipid measurements expressed in $\mathrm{mg} / \mathrm{dL}$. TThe $\mathrm{p}$-values are for the corresponding adjusted means on the log scale.

TG, triglyceride; LDL-C, low density lipoprotein-cholesterol; HDL, high density lipoprotein; SS, individuals homozygous for the Ser447 allele; $S X+X X$, individuals that carry either one or two $447 X$ alleles. 
phism within LPL has been associated with alterations in the TG/HDL-C ratio [46], no study has previously explored the impact of this polymorphism on the ratio. However, one may infer that similar findings were demonstrated in the longitudinal analysis of the Bogalusa Heart Study (i.e., increased frequency of $447 \mathrm{X}$ in subjects in the bottom quartile for plasma TG and HDL-C) [41].

Though several studies have examined the co-segregation of genetic variations within the LPL gene region with the occurrence of FCH [23], the few that have examined the role of the 447X allele lacked sufficient power to evaluate the significance of this polymorphism in $\mathrm{FCH}$. Of the four studies that examined the S447X polymorphism in 31 [47], 40 [36], 20 [37], and 30 [34] unrelated probands, respectively, only Campagna and colleagues [34] reported a modest effect of the S447X polymorphism on lipid levels. Given the frequency of this polymorphism and the sample sizes of these aforementioned studies, detection of the genetic association reported here would not be expected.

Potential study limitations include a possibility of selection bias of combined hyperlipidemia subjects without the use of familial primary dyslipidemia criterion. A goal of our group is to identify an endophenotype that would allow the identification of individuals with FCH without the resource intensive assessment of relatives. However, it is important to note that our group has successfully validated several genetic associations reported for FCH $[48,49]$. Another potential limitation involved the availability of BMI, an index known to impact lipoprotein metabolism and lipid homeostasis $[46,50]$, in the entire study sample for inclusion in regression analyses.

\section{Summary}

As one would expect in a multifactorial model of a common disease, contributive alleles would be expected to add an incremental risk of disease (i.e., CAD). Common deficiencies in LPL may be the underlying causes of significant increases in CAD risk $[1,2]$. Understanding the role that functional gene polymorphisms play in risk and determining the levels of intermediate phenotypes (e.g., TG) is essential to our understanding of the important metabolic pathways in the diseased and disease-free state. Given the prevalence of the LPL S447X polymorphism in the population, greater knowledge of the underlying consequences of this variation may be of considerable importance in understanding genetic predisposition to atherosclerosis and heart disease [51]. S447X is a common, functional variant and is associated with a beneficial lipid profile, and is significantly depleted in patients with combined hyperlipidemia. Importantly, understanding the contribution not only of susceptibility alleles in dyslipidemia, but also of depletion of protective alleles, may contribute materially to the identification of the genetic determinants of heart disease.

\section{Methods \\ Study design}

This study was a retrospective analysis of the prevalence of a common LPL polymorphism in non-Hispanic Caucasian (European-descent) subjects with combined hyperlipidemia and a control group. Subjects were selected from the University of California, San Francisco (UCSF) Genomic Resource in Arteriosclerosis [52], using the following criteria: combined hyperlipidemia with total plasma cholesterol (TC) $>200 \mathrm{mg} / \mathrm{dL}$, total plasma TG > $200 \mathrm{mg} / \mathrm{dL}$, LDL-C > $130 \mathrm{mg} / \mathrm{dL}$, and very low density lipoprotein-cholesterol (VLDL-C) $>30 \mathrm{mg} / \mathrm{dL}$. Exclusion criteria were: a diagnosis of familial hypercholesterolemia, hypothyroidism, or Type 2 Diabetes Mellitus. Healthy non-Hispanic Caucasian (European-descent) subjects with normal lipoprotein profiles comprised the control group. All subjects gave informed consent in a protocol approved by the UCSF Committee on Human Research. With the exception of Body Mass Index (BMI, $\mathrm{n}$ = 247) clinical and demographic data were available on all subjects $(\mathrm{n}=373)$.

\section{Genotypic and phenotypic studies}

Genomic DNA was prepared from whole blood and was drawn after a 10-hour fast [52]. VLDL were prepared by ultracentrifugation [53]. HDL-C was measured after precipitation of apo-B-containing lipoproteins with dextran sulfate and magnesium [54]. Cholesterol and TG levels were measured in plasma and in lipoprotein fractions by either automated fluorescence method or automated chemical analysis [55]. LDL-C was calculated as TC minus HDL-C plus VLDL-C. Standards were provided by the Centers for Disease Control (Atlanta, Georgia, USA). Baseline lipoprotein measurements were obtained when patients had received no lipid lowering medication for at least 1 month. The presence or absence of the S447X polymorphism was determined as described previously [17].

\section{Statistical methods}

The SPSS for Windows (v11.0.1, 2001) system for statistical analysis was used. Allele and genotype frequencies were determined by the gene-counting method. Tests for Hardy-Weinberg equilibrium in controls, and allelic or genotypic association in cases versus controls, were evaluated by $\chi^{2}$ test. $\chi^{2}$ tests of allele frequency were adjusted using Yates' Continuity Correction. Power transformations of potential predictor variables were examined where appropriate. Two-group comparisons of means of transformed or normally distributed variables used the independent samples t-test. Two-group comparisons of means of untransformed, non-normally distributed variables used the Wilcoxon two-sample test. The procedure, 
general linear model (GLM), was used for linear regression models. Power transformations of potential predictor variables were examined to maximize the explanatory power of the overall model (by maximizing the F statistic). Interactions between covariates and genotypes were evaluated. Selected interaction effects and covariateadjusted means of the transformed responses for levels of categorical factors were tested using procedure GLM. Interaction effects with $\mathrm{p}<0.10$ were retained. For multiple comparisons between factor levels, Bonferroni-corrected p-values are reported.

\section{Competing interests}

The author(s) declare that they have no competing interests.

\section{Authors' contributions}

SFW carried out genetic analyses, participated in the statistical analysis and coordinated the preparation of the manuscript. MVK carried out genetic analyses. CRP managed the genomic resource from which study subjects were identified, provided specimens for analysis and participated in manuscript preparation. MJM recruited study subjects and participated in the study design and manuscript preparation. JPK recruited study subjects and participated in the study design and manuscript preparation. BEA conceived of the study, participated in its design and coordination, statistical analyses, and participated in manuscript preparation.

\section{Acknowledgements}

The Hellman Family Award supported Dr. Aouizerat. This work was also supported by grants from Pharmacia Corporation (D 91.101), California Discovery Grant (bio04- 10482), AAI I 205, HL50779 and HL50782. Dr. Wung was a fellow of the Summer Genetic Institute, National Institute of Nursing Research/National Institutes of Health in 2002.

\section{References}

I. Farmer JA, Gotto AMJ: Dyslipidemia and the vulnerable plaque. Prog Cardiovasc Dis 2002, 44(6):415-428.

2. Wilson PW, Castelli WP, Kannel WB: Coronary risk prediction in adults (the Framingham Heart Study). Am J Cardiol 1987, 59(14):9IG-94G.

3. Lusis AJ: Atherosclerosis. Nature 2000, 407(680I):233-24I.

4. Hokanson JE, Austin MA: Plasma triglyceride level is a risk factor for cardiovascular disease independent of high-density lipoprotein cholesterol level: a meta-analysis of populationbased prospective studies. J Cardiovasc Risk 1996, 3(2):2 I3-219.

5. Hokanson JE: Functional variants in the lipoprotein lipase gene and risk cardiovascular disease. Curr Opin Lipidol 1999, I0(5):393-399.

6. Wittrup HH, Nordestgaard BG, Steffensen R, Jensen G, TybjaergHansen A: Effect of gender on phenotypic expression of the S447X mutation in LPL: the Copenhagen City Heart Study. Atherosclerosis 2002, 165(I): I19-126.

7. Fisher RM, Humphries SE, Talmud PJ: Common variation in the lipoprotein lipase gene: effects on plasma lipids and risk of atherosclerosis. Atherosclerosis 1997, 135(2): 145-159.

8. Otarod JK, Goldberg IJ: Lipoprotein lipase and its role in regulation of plasma lipoproteins and cardiac risk. Curr Atheroscler Rep 2004, 6(5):335-342.

9. Taskinen MR, Nikkila EA: High density lipoprotein subfractions in relation to lipoprotein lipase activity of tissues in man--evi- dence for reciprocal regulation of HDL2 and HDL3 levels by lipoprotein lipase. Clin Chim Acta I98I, I I 2(3):325-332.

10. Clee SM, Bissada N, Miao F, Miao L, Marais AD, Henderson HE, Steures P, McManus J, McManus B, LeBoeuf RC, Kastelein J], Hayden MR: Plasma and vessel wall lipoprotein lipase have different roles in atherosclerosis. J Lipid Res 2000, 4I(4):52I-53I.

II. Malloy MJ, Kane JP: A risk factor for atherosclerosis: triglyceride-rich lipoproteins. Adv Intern Med 200 I, 47:III-I36.

12. Rapp JH, Harris HW, Hamilton RL, Krupski WC, Reilly LM, Ehrenfeld WK, Stoney RJ, Goldstone J, Kane JP: Particle size distribution of lipoproteins from human atherosclerotic plaque: a preliminary report. J Vasc Surg 1989, 9(I):8I-88.

13. Fojo SS, Brewer HB: Hypertriglyceridaemia due to genetic defects in lipoprotein lipase and apolipoprotein C-II. J Intern Med 1992, 23 I (6):669-677.

14. Hayden MR, Ma Y: Molecular genetics of human lipoprotein lipase deficiency. Mol Cell Biochem 1992, I I3(2): I7I-I76.

15. Gilbert B, Rouis M, Griglio S, de Lumley L, Laplaud P: Lipoprotein lipase (LPL) deficiency: a new patient homozygote for the preponderant mutation Gly $188 \mathrm{Glu}$ in the human LPL gene and review of reported mutations: $75 \%$ are clustered in exons 5 and 6. Ann Genet 200I, 44(I):25-32.

16. Kobayashi J, Nishida T, Ameis D, Stahnke G, Schotz MC, Hashimoto H, Fukamachi I, Shirai K, Saito Y, Yoshida S: A heterozygous mutation (the codon for Ser447----a stop codon) in lipoprotein lipase contributes to a defect in lipid interface recognition in a case with type I hyperlipidemia. Biochem Biophys Res Commun 1992, 182(I):70-77.

17. Humphries SE, Nicaud V, Margalef J, Tiret L, Talmud PJ: Lipoprotein lipase gene variation is associated with a paternal history of premature coronary artery disease and fasting and postprandial plasma triglycerides: the European Atherosclerosis Research Study (EARS). Arterioscler Thromb Vasc Biol 1998, I8(4):526-534

18. Zhang H, Henderson H, Gagne SE, Clee SM, Miao L, Liu G, Hayden MR: Common sequence variants of lipoprotein lipase: standardized studies of in vitro expression and catalytic function. Biochim Biophys Acta 1996, I302(2): 159-166.

19. Gagne SE, Larson MG, Pimstone SN, Schaefer EJ, Kastelein J], Wilson PW, Ordovas JM, Hayden MR: A common truncation variant of lipoprotein lipase (Ser447X) confers protection against coronary heart disease: the Framingham Offspring Study. Clin Genet 1999, 55(6):450-454.

20. Ross CJ, Liu G, Kuivenhoven JA, Twisk J, Rip J, van Dop W, Excoffon KJ, Lewis SM, Kastelein J], Hayden MR: Complete rescue of lipoprotein lipase-deficient mice by somatic gene transfer of the naturally occurring LPLS447X beneficial mutation. Arterioscler Thromb Vasc Biol 2005, 25( (10):2 I 43-2150.

21. Rader DJ: Gain-of-function mutations and therapeutic implications: lipoprotein lipase S447X to the rescue. Arterioscler Thromb Vasc Biol 2005, 25(I0):2018-2019.

22. Strauss JG, Frank S, Kratky D, Hammerle G, Hrzenjak A, Knipping G, von Eckardstein A, Kostner GM, Zechner R: Adenovirus-mediated rescue of lipoprotein lipase-deficient mice. Lipolysis of triglyceride-rich lipoproteins is essential for high density lipoprotein maturation in mice. I Biol Chem 200I, 276(39):36083-36090

23. Aouizerat BE, Allayee $H$, Bodnar J, Krass KL, Peltonen L, de Bruin TW, Rotter Jl, Lusis AJ: Novel genes for familial combined hyperlipidemia. Curr Opin Lipidol 1999, I 0(2): I I3-122.

24. Eurlings PM, van der Kallen C], Geurts JM, van Greevenbroek MM, de Bruin TW: Genetic dissection of familial combined hyperlipidemia. Mol Genet Metab 200I, 74(I-2):98- 104.

25. Goldstein JL, Schrott HG, Hazzard WR, Bierman EL, Motulsky AG: Hyperlipidemia in coronary heart disease. II. Genetic analysis of lipid levels in 176 families and delineation of a new inherited disorder, combined hyperlipidemia. I Clin Invest 1973, 52(7): I544-1568.

26. Nikkila EA, Aro A: Family study of serum lipids and lipoproteins in coronary heart-disease. Lancet 1973, I(78 I 0):954-959.

27. Rose HG, Kranz P, Weinstock M, Juliano J, Haft Jl: Inheritance of combined hyperlipoproteinemia: evidence for a new lipoprotein phenotype. Am J Med 1973, 54(2): I48-160.

28. Sniderman A, Shapiro S, Marpole D, Skinner B, Teng B, Kwiterovich $\mathrm{PO}$ : Association of coronary atherosclerosis with hyperapobetalipoproteinemia [increased protein but normal choles- 
terol levels in human plasma low density (beta) lipoproteins]. Proc Natl Acad Sci U S A 1980, 77(I):604-608.

29. Venkatesan S, Cullen P, Pacy P, Halliday D, Scott J: Stable isotopes show a direct relation between VLDL apoB overproduction and serum triglyceride levels and indicate a metabolically and biochemically coherent basis for familial combined hyperlipidemia. Arterioscler Thromb 1993, 13(7): I I 10-I I I8.

30. Austin MA, Brunzell JD, Fitch WL, Krauss RM: Inheritance of low density lipoprotein subclass patterns in familial combined hyperlipidemia. Arteriosclerosis 1990, 10(4):520-530.

3I. de Graaf J, Hak-Lemmers HL, Hectors MP, Demacker PN, Hendriks JC, Stalenhoef AF: Enhanced susceptibility to in vitro oxidation of the dense low density lipoprotein subfraction in healthy subjects. Arterioscler Thromb 1991, I I (2):298-306.

32. Babirak SP, Brown BG, Brunzell JD: Familial combined hyperlipidemia and abnormal lipoprotein lipase. Arterioscler Thromb 1992, I 2(10): I |76-II83.

33. Seed M, Mailly F, Vallance D, Doherty E, Winder A, Talmud P, Humphries SE: Lipoprotein lipase activity in patients with combined hyperlipidaemia. Clin Investig 1994, 72(2): 100-106.

34. Campagna F, Montali A, Baroni MG, Maria AT, Ricci G, Antonini R, Verna $R$, Arca M: Common variants in the lipoprotein lipase gene, but not those in the insulin receptor substrate- $I$, the beta3-adrenergic receptor, and the intestinal fatty acid binding protein-2 genes, influence the lipid phenotypic expression in familial combined hyperlipidemia. Metabolism 2002, 5 I (10): I 298-1305.

35. de Bruin TW, Mailly F, van Barlingen HH, Fisher R, Castro Cabezas M, Talmud P, Dallinga-Thie GM, Humphries SE: Lipoprotein lipase gene mutations D9N and N29 IS in four pedigrees with familial combined hyperlipidaemia. Eur J Clin Invest 1996 26(8):63|-639.

36. Hoffer MJ, Bredie SJ, Snieder H, Reymer PW, Demacker PN, Havekes LM, Boomsma DI, Stalenhoef AF, Frants RR, Kastelein J]: Genderrelated association between the -93T-->G/D9N haplotype of the lipoprotein lipase gene and elevated lipid levels in familial combined hyperlipidemia. Atherosclerosis 1998, I 38(I):91-99.

37. Nevin DN, Brunzell JD, Deeb SS: The LPL gene in individuals with familial combined hyperlipidemia and decreased LPL activity. Arterioscler Thromb 1994, 14(6):869-873.

38. Reymer PW, Groenemeyer BE, Gagne E, Miao L, Appelman EE, Seidel JC, Kromhout D, Bijvoet SM, van de Oever K, Bruin T, et al.: A frequently occurring mutation in the lipoprotein lipase gene (Asn29 ISer) contributes to the expression of familial combined hyperlipidemia. Hum Mol Genet 1995, 4(9): 1543-I549.

39. Ledmyr H, Karpe F, Lundahl B, McKinnon M, Skoglund-Andersson C Ehrenborg E: Variants of the microsomal triglyceride transfer protein gene are associated with plasma cholesterol levels and body mass index. J Lipid Res 2002, 43(I):5I-58.

40. Couture P, Otvos JD, Cupples LA, Wilson PW, Schaefer EJ, Ordovas JM: Absence of association between genetic variation in the promoter of the microsomal triglyceride transfer protein gene and plasma lipoproteins in the Framingham Offspring Study. Atherosclerosis 2000, 148(2):337-343.

4I. Chen W, Srinivasan SR, Elkasabany A, Ellsworth DL, Boerwinkle E, Berenson GS: Influence of lipoprotein lipase serine 447 stop polymorphism on tracking of triglycerides and HDL cholesterol from childhood to adulthood and familial risk of coronary artery disease: the Bogalusa heart study. Atherosclerosis 200I, I 59(2):367-373.

42. Jemaa R, Fumeron F, Poirier O, Lecerf L, Evans A, Arveiler D, Luc G, Cambou JP, Bard JM, Fruchart JC, et al.: Lipoprotein lipase gene polymorphisms: associations with myocardial infarction and lipoprotein levels, the ECTIM study. Etude Cas Temoin sur I'Infarctus du Myocarde. J Lipid Res 1995, 36( I 0):2 I4I-2 I 46.

43. Kuivenhoven JA, Groenemeyer BE, Boer JM, Reymer PW, Berghuis R, Bruin $T$, Jansen $H$, Seidell JC, Kastelein J]: Ser447stop mutation in lipoprotein lipase is associated with elevated HDL cholesterol levels in normolipidemic males. Arterioscler Thromb Vasc Biol 1997, I7(3):595-599.

44. Wittrup HH, Tybjaerg-Hansen A, Nordestgaard BG: Lipoprotein lipase mutations, plasma lipids and lipoproteins, and risk of ischemic heart disease. A meta-analysis. Circulation 1999. 99(22):290I-2907.

45. Zhang Q, Cavanna J, Winkelman BR, Shine B, Gross W, Marz W, Galton DJ: Common genetic variants of lipoprotein lipase that relate to lipid transport in patients with premature coronary artery disease. Clin Genet 1995, 48(6):293-298.

46. Senti M, Bosch M, Aubo C, Elosua R, Masia R, Marrugat J: Relationship of abdominal adiposity and dyslipemic status in women with a common mutation in the lipoprotein lipase gene. The REGICOR investigators. Atherosclerosis 2000, I 50(I): I35-I4I.

47. Gagne E, Genest J], Zhang H, Clarke LA, Hayden MR: Analysis of DNA changes in the LPL gene in patients with familial combined hyperlipidemia. Arterioscler Thromb 1994, I 4(8): | 250- 257.

48. Aouizerat BE, Kulkarni M, Heilbron D, Drown D, Raskin S, Pullinger CR, Malloy MJ, Kane JP: Genetic analysis of a polymorphism in the human apolipoprotein A-V gene: effect on plasma lipids. J Lipid Res 2003, I:I

49. Kane JP, Aouizerat BE, Luke MM, Shiffman D, lakoubova O, Liu D, Rowland CM, Catanese JJ, Leong DU, Lau KF, Louie JZ, Tong CH, McAllister LB, Dabby LF, Ports TA, Michaels AD, Zellner C, Pullinger CR, Malloy MJ, Devlin J]: Novel Genetic Markers For Structural Coronary Artery Disease, Myocardial Infarction, And Familial Combined Hyperlipidemia: Candidate And Genome Scans Of Functional SNPS. Proceedings of the International Symposium on Arteriosclerosis 2004:309-3 I2.

50. Joshi AV, Day D, Lubowski TJ, Ambegaonkar A: Relationship between obesity and cardiovascular risk factors: findings from a multi-state screening project in the United States. Curr Med Res Opin 2005, 2I(II): I755-176I.

5I. Evans V, Kastelein J]: Lipoprotein lipase deficiency--rare or common? Cardiovasc Drugs Ther 2002, 16(4):283-287.

52. Pullinger CR, Hennessy LK, Chatterton JE, Liu W, Love JA, Mendel CM, Frost PH, Malloy MJ, Schumaker VN, Kane JP: Familial liganddefective apolipoprotein $\mathrm{B}$. Identification of a new mutation that decreases LDL receptor binding affinity. J Clin Invest 1995, 95(3): 1225-1234.

53. Havel RJ, Eder HA, Bragdon JH: The distribution and chemical composition of ultracentrifugally separated lipoproteins in human serum. J Clin Invest 1955, 34(9): 1345-I353.

54. Warnick GR, Benderson J, Albers J]: Dextran sulfate-Mg2+ precipitation procedure for quantitation of high-density-lipoprotein cholesterol. Clin Chem 1982, 28(6): I379- I 388

55. Kane JP, Malloy MJ, Ports TA, Phillips NR, Diehl JC, Havel RJ: Regression of coronary atherosclerosis during treatment of familial hypercholesterolemia with combined drug regimens. Jama 1990, 264(23):3007-3012.

Publish with Bio Med Central and every scientist can read your work free of charge

"BioMed Central will be the most significant development for disseminating the results of biomedical research in our lifetime. "

Sir Paul Nurse, Cancer Research UK

Your research papers will be:

- available free of charge to the entire biomedical community

- peer reviewed and published immediately upon acceptance

- cited in PubMed and archived on PubMed Central

- yours - you keep the copyright 